\title{
MICROPROPAGATION OF PLANTAGO MARITIMA L. - A VANISHING SPECIES IN POLAND
}

\author{
JOANNA MAKOWCZYŃSKA, EMILIA ANDRZEJEWSKA-GOLEC* \\ Department of Biology and Pharmaceutical Botany, \\ Medical University of Łódź \\ Muszyńskiego 1, 90-151 Łódź, Poland \\ * e-mail: e.andrzejewska@wp.pl
}

(Received: November 24, 2008. Accepted: February 25, 2009)

\begin{abstract}
A vanishing species in Poland - Plantago maritima L. was regenerated in vitro from tips of shoots (obtained in vitro) and from different explants of 4-week-old seedlings: seedling tips, hypocotyls, cotyledons, roots. Murashige and Skoog basal medium, supplemented with $0.6 \mu \mathrm{M}$ indole-3-acetic acid in combination with cytokinins 6-benzyladenine, zeatin or kinetin, was used. The plants obtained in the result of micropropagation were normal in appearence. It was proved that Plantago maritima species was amenable to propagation from different kinds of explants. The method may be of significance for protection of sea plantain.
\end{abstract}

KEY WORDS: micropropagation, organogenesis, Plantaginaceae, root regeneration, sea plantain.

\section{INTRODUCTION}

A salt marsh plant, herbaceous perennial, sea plantain Plantago maritima L. (Plantaginaceae) is a vanishing species in Poland (category "vulnerable" in Polish Red Book), under compact active protection (Piotrowska 2001; www). Many localities of sea plantain disappeared long time ago as a result of drainage, destruction of salt marshes or cessation of grazing. P. maritima nowadays grows in Poland only at the mouth of the Odra River and Bays of Puck and Gdansk (Piotrowska 2001).

$P$. maritima is sometimes used as soothing expectorant and stomachicum (Liebezeit et al. 1999). The phytochemical studies have shown that this plant contains several interesting metabolites: iridoid glucosides (aucubin, mellitoside, rehmannioside D), phenylethanoid glycosides (echinacoside), flavonoids, tannins, polysaccharides, sorbitol (Moore et al. 1972; Ahmad 1979; Liebezeit et al. 1999; Rønsted et al. 2000; Grubešić et al. 2005).

To the best of our knowledge, there was not any original paper on culture in vitro of $P$. maritima. There is only

\footnotetext{
Abbreviations

BA - 6-benzyladenine; 2,4-D - 2,4-dichlorophenoxyacetic acid; GA gibberellic acid; IAA - indole-3-acetic acid; IBA - indole-3-butyric acid; KIN - kinetin; MR - multiplication rate, evaluated as the mean number of shoots (or also and buds) on one explant at the end of the multiplication cycle (6 weeks); MS - Murashige and Skoog (1962) medium; NAA - naphthaleneacetic acid; TDZ - thidiazuron; ZEA - zeatin
}

a summary from congress on in vitro biology described propagation of this species as a model to study the role of polyol accumulation in salt tolerance (Chang and Locy 1996). Moreover, Liebezeit et al. (1999), describing P. maritima, suggested only that this species "can be of potential interest to biotechnologists". Our preliminary experiments with $P$. maritima in vitro were presented in 3rd Country Congress of Biotechnology in Poznań (Makowczyńska and Andrzejewska-Golec 2007).

\section{MATERIAL AND METHODS}

\section{Sources of explants}

- 4-week-old Plantago maritima seedlings from seeds provided by the Jardine Botanique de la Ville et de l'Université, Besançon (France), because of legal protection of $P$. maritima in Poland (see: Introduction). Seeds were surface-sterilized by immersion in $2.0 \%$ sodium hypochlorite for $10 \mathrm{~min}$. and then germinated (MS supplemented with $0.9 \mu \mathrm{M}$ KIN and $2.9 \mu \mathrm{M} \mathrm{GA}_{3}$ ) as it was previously described for the seeds of $P$. asiatica L. (Makowczyńska and Andrzejewska-Golec 2003);

- shoots derived from the in vitro culture.

\section{Kind of explants}

- from seedlings: tips (approximately $0.5 \mathrm{~cm}$ long), hypocotyls (approximately $0.5-1.0 \mathrm{~cm}$ long), roots (approximately $1 \mathrm{~cm}$ long), cotyledons (cultured whole); - from shoots: tips (approximately $0.5 \mathrm{~cm}$ long); 


\section{Conditions of in vitro culture}

Conditions were the same as it had been successfully used previously by the authors for micropropagation of other Plantago genus taxa: $P$. asiatica L. and $P$. camtschatica Link: MS medium solidified with $0.7 \%$ agar; $\mathrm{pH}$ adjusted to $5.6-5.9 ; 26 \pm 2^{\circ} \mathrm{C}$; light $40 \mu \mathrm{M} / \mathrm{m}^{2} \mathrm{~s}$; humidity 80 -90\% (Makowczyńska and Andrzejewska-Golec 2003; Andrzejewska-Golec and Makowczyńska 2008).

The cultures were continued in a growth cabinet for 6 weeks. For each treatment about 9-15 explants in 2 replicas were used.

\section{Growth regulators used in experiments}

- auxin: $0.6 \mu \mathrm{M}$ IAA

- cytokinins: $0.2,0.4,2.2,4.4,6.7,8.9 \mu \mathrm{M}$ BA - for shoots formed from tips of seedlings;

2.2 and $4.4 \mu \mathrm{M} \mathrm{BA}$ - for shoots formed from tips of shoots cultured in vitro;

$0.9,8.9,22.2 \mu \mathrm{M}$ BA, 0.9, 9.3, 23.2 $\mathrm{\mu M}$ KIN or $0.9,9.1$, $22.8 \mu \mathrm{M}$ ZEA - for adventitious shoots regeneration from hypocotyls, cotyledons and roots

\section{Rooting of shoots}

MS alone or MS in combination with auxins: IAA, IBA or NAA (concentration - Table 3) were used.

\section{Acclimatisation}

Acclimatisation was conducted in flower pots for two months.

\section{RESULTS}

Shoot formation from seedling tips (Table 1; Fig. 1E)

The greatest multiplication rate MR of buds and shoots obtained by us for 6-week culture of seedlings tips of $P$. maritima was $8.8 \pm 1.3$. However near $60 \%$ of buds and shoots were abnormal (less or more hydrous or deformed). The great MR of all shoots (normal and abnormal) was of $4.5 \pm 0.9$, but in case of normal shoots $-3.8 \pm 1$ for concentration $6.7 \mu \mathrm{M}$ of BA.

After the 6-week culture of seedling tips we observed roots only in low concentrations of BA: $0.4 \mu \mathrm{M}-15 \%$ and $0.2 \mu \mathrm{M}-50 \%$ rooted explants.

Shoots after 6 week culture obtained under $1.5 \mathrm{~cm}$ height.
Shoot formation on the tips

of shoots derived from in vitro culture (Table 1; Fig. 1A)

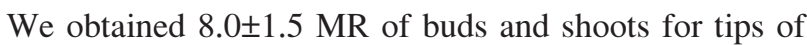
shoots derived from in vitro culture, but parts of buds and shoots were abnormal (less or more hydrous and deformed). MR of normal shoots was $-3.8 \pm 0.9$. Shoots obtained on this way were higher than in case of seedling tips culture.

\section{Shoot regeneration}

from hypocotyls, cotyledons, roots (Table 2; Fig. 1B-D)

We have obtained better results of MR for the hypocotyl, cotyledon and root explants than for tips. The highest MR $-28.3 \pm 4.1$ was obtained in case of root explants cultured on MS supplemented with $0.6 \mu \mathrm{M}$ IAA and $22.8 \mu \mathrm{M}$ ZEA. Adventitious shoots on these 3 kind of explants were regenerated directly and indirectly. Callus was formed especially on root explants: on 30-90\% root explants, according to a kind and concentration of cytokinin (90\% for 0.9 $\mu \mathrm{M} B \mathrm{~B})$.

The rooting of shoots

(without roots after 6-week culture) (Table 3)

The 4-week rooting was the most effective (nearly 90\%) in the case of application of MS supplemented with auxin NAA in the concentration of $0.5 \mu \mathrm{M}$, and the lowest (nearly $55 \%$ ) - in the case of auxin IBA in the concentration of $2.5 \mu \mathrm{M}$.

\section{Acclimatisation}

For two months of the acclimatisation in flower pots, $75 \%$ of plants regenerated from seedling tips and $40 \%$ of plants regenerated from other seedling explants survived. Plants blossomed in 2-month of the pot culture (Fig. $1 \mathrm{E}$ and $\mathrm{F})$. Following adaptation the plants were transferred into the ground in the Garden of Medicinal Plants, Department of Pharmacognosy, Medical University of Łódź.

The plants obtained as a result of micropropagation were phenotypically normal with respect to leaf shape, spike constitution and growth features during growth stages (Fig. 1E).

TABLE 1. Effect of various concentration cytokinin BA and $0.6 \mu \mathrm{M}$ IAA added to MS on shoot micropropagation of Plantago maritima from seedling tips and from shoot tips.

\begin{tabular}{|c|c|c|c|c|c|c|}
\hline Kind of explants & $\begin{array}{c}\mathrm{BA} \\
(\mu \mathrm{M})\end{array}$ & $\begin{array}{c}\text { MR of buds } \\
\text { and shoots } \\
\pm \text { SE }\end{array}$ & $\begin{array}{l}\text { Abnormal buds } \\
\text { and shoots } \\
(\%)\end{array}$ & $\begin{array}{c}\text { MR of all shoots } \\
\quad \pm \mathrm{SE}\end{array}$ & $\begin{array}{c}\text { Mean shoot length } \\
\pm \mathrm{SE} \\
(\mathrm{cm})\end{array}$ & $\begin{array}{c}\mathrm{MR} \\
\text { of normal shoots } \\
\pm \mathrm{SE}\end{array}$ \\
\hline \multirow[t]{6}{*}{ Seedling tips * } & 0.2 & $6.1 \pm 1.6$ & 40.3 & $3.4 \pm 0.7$ & $1.8 \pm 0.3$ & $3.2 \pm 0.7$ \\
\hline & 0.4 & $2.8 \pm 1.3$ & 58.8 & 0 & 0 & 0 \\
\hline & 2.2 & $8.8 \pm 1.3$ & 58.5 & $2.9 \pm 07$ & $1.6 \pm 0.2$ & $2.3 \pm 0.6$ \\
\hline & 4.4 & $6.0 \pm 1.0$ & 64.3 & $3.3 \pm 1.1$ & $2.0 \pm 0.2$ & $2.6 \pm 0.8$ \\
\hline & 6.7 & $7.5 \pm 1.5$ & 58.3 & $4.5 \pm 0.9$ & $1.6 \pm 0.1$ & $3.8 \pm 1.0$ \\
\hline & 8.9 & $3.8 \pm 0.9$ & 50.0 & $4.3 \pm 0.3$ & $1.7 \pm 0.3$ & $2.7 \pm 0.3$ \\
\hline \multirow[t]{2}{*}{ Shoot tips $*$} & 2.2 & $8.0 \pm 1.5$ & 37.0 & $4.2 \pm 0.9$ & $2.7 \pm 0.2$ & $3.8 \pm 0.9$ \\
\hline & 4.4 & $5.9 \pm 1.1$ & 64.5 & $3.0 \pm 0.8$ & $2.7 \pm 0.5$ & $2.0 \pm 0.4$ \\
\hline
\end{tabular}

SE - standard error of the mean

For each treatment about 20-30 explants were used

* see: Material and methods 

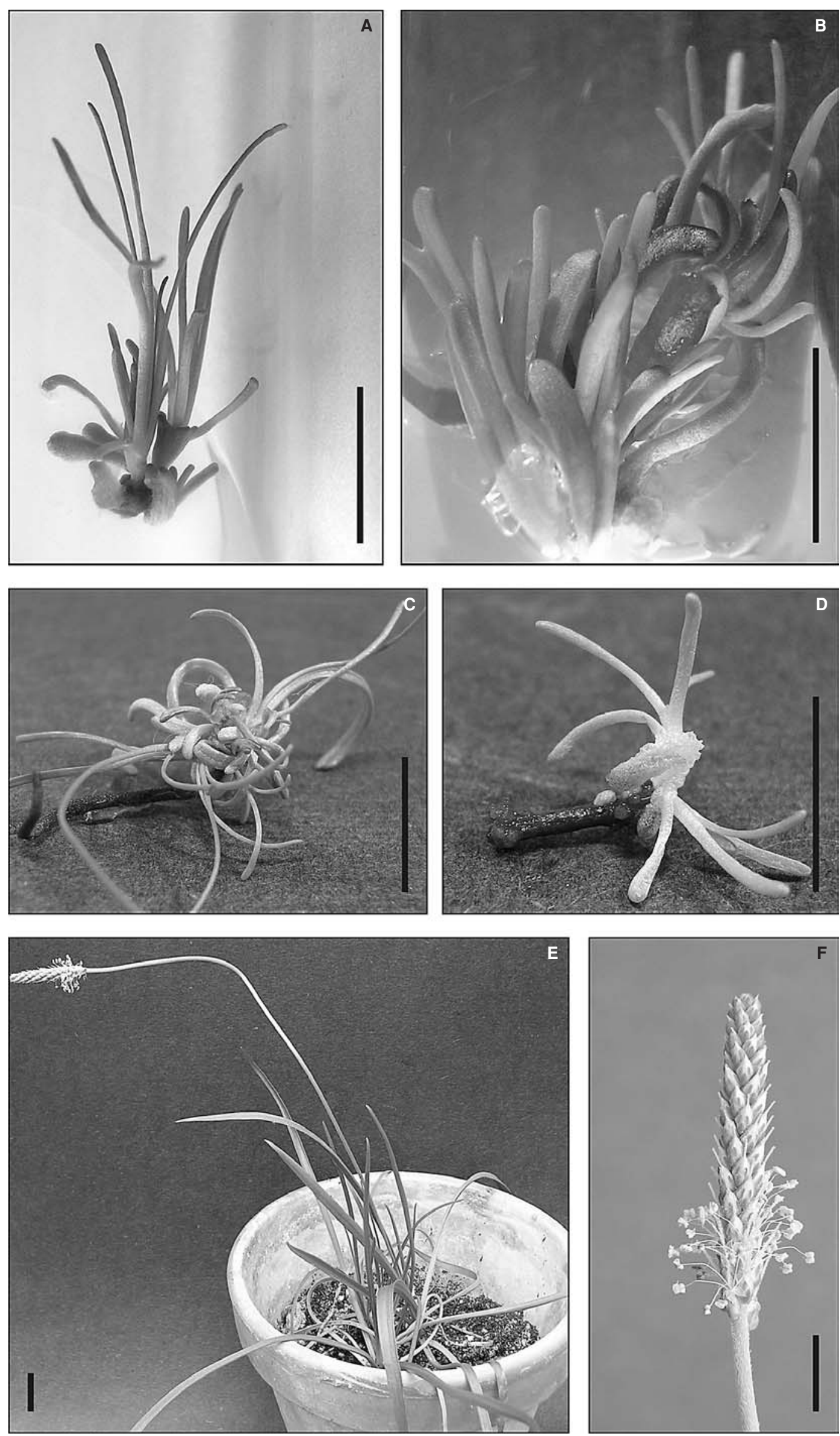

Fig. 1. In vitro propagation of Plantago maritima L. A - micropropagation via shoot-tip method. MS $+2.2 \mu \mathrm{M} \mathrm{BA}+0.6 \mu \mathrm{M}$ IAA; B - organogenesis on

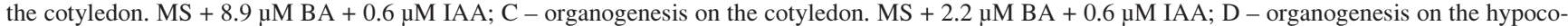
tyl. MS + 2.2 $\mu \mathrm{M}$ BA + 0.6 $\mu \mathrm{M}$ IAA; E - 2-month blooming plant in vitro regenerated from seedling tips; $\mathrm{F}$ - spike of these plant (E). Bar $1 \mathrm{~cm}$. 
TABLE 3. Percentage of the adventitions shoot rooting. MS medium

\begin{tabular}{lccccc}
\hline $\begin{array}{l}\text { Kind } \\
\text { of auxin } \\
(\mu \mathrm{M})\end{array}$ & \multicolumn{2}{l}{ Week of culture } \\
\cline { 2 - 6 } & & 1 & 2 & 3 & 4 \\
\hline Control without auxin & 16.2 & 41.9 & 45.2 & 48.4 \\
\hline IAA & 0.6 & 33.3 & 75.0 & 75.0 & 75.0 \\
& 2.9 & 27.6 & 55.2 & 62.1 & 69.0 \\
\hline IBA & 0.5 & 46.9 & 65.6 & 75.0 & 75.0 \\
& 2.5 & 6.5 & 35.5 & 41.9 & 54.8 \\
\hline \multirow{2}{*}{ NAA } & 0.5 & 27.6 & 82.8 & 86.2 & 89.7 \\
& 2.7 & 0 & 61.3 & 67.7 & 67.7 \\
\hline
\end{tabular}

\section{DISCUSSION}

There is a little information in the literature on in vitro culture of $P$. maritima. It is only a short summary from Congress on In Vitro Biology in San Francisco in 1996 year (Chang and Locy 1996). Authors regenerated P. mariti$m a$ exclusively on leaf explants. Instead we multiplicated this plant from different explants: seedling tips, shoot tips, roots, cotyledons and hypocotyls. Chang and Locy (1996) used MS basal salt, Gamborg B5 vitamins, 2\% sorbitol, 0.6 $\mu \mathrm{M}$ NAA and $8.9 \mu \mathrm{M}$ BA for direct regeneration of adventitious shoots on leaf explants. The optimum medium for callus growth contained the same basal salt and vitamins with $2 \%$ sucrose, $4.5 \mu \mathrm{M}$ 2,4-D, $2.3 \mu \mathrm{M}$ KIN and $1 \mathrm{~g} / \mathrm{l}$ activated carbon. Callus transferred to the same medium containing $5 \mathrm{~g} / \mathrm{l}$ activated carbon readily regenerated shoots. They obtained plants normal in appearance. These plants flowered and produced normal fertile seeds.

In our work multiplication of $P$. maritima through seedling tips is first described, but seedling tips were used with success for multiplication of another taxa of the genus Plantago: P. asiatica L., P. camtschatica Link, $P$. ovata Forsk. (Barna and Wakhlu 1988; Pramanik et al. 1995; Makowczyńska and Andrzejewska-Golec 2003; Andrzejewska-Golec and Makowczyńska 2008). In case of multiplication of these three plantain, as in our present work, also MS medium with cytokinin BA and auxin IAA (and also KIN or NAA) were used. The best effect (MR = 18) obtained Pramanik et al. (1995) for $P$. ovata in case MS with $1.1 \mu \mathrm{M}$ IAA and $22.2 \mu \mathrm{M}$ IBA. In our previous study concerning $P$. camtschatica a better effect was obtained for the culture of tips of shoots derived from in vitro than for culture of seedling tips (Andrzejewska-Golec and Makowczyńska 2008). Now we obtained similar effects for seedling tips and shoot tips of P. maritima. We have obtained better results of MR for hypocotyl, cotyledon and root explants than for tips. The best effect $(\mathrm{MR}=$ 28.3 \pm 4.4 ) we obtained in case of root explants cultured on MS supplemented with $0.6 \mu \mathrm{M}$ IAA and $22.8 \mu \mathrm{M}$ ZEA. Khawar et al. (2005) obtained MR near 25 for cotyledon and near 19 for hypocotyl in case of Plantago lanceolata (MS supplemented with $1.34 \mu \mathrm{M}$ NAA and $3.33 \mu \mathrm{M} \mathrm{BA}$ ). Instead Budzianowska et al. (2004) on average 4.38 new rosetts from leaf segments and 4.0 from root explants obtained for $P$. lanceolata (MS medium supplemented 11.42 $\mu \mathrm{M}$ IAA and $9.29 \mu \mathrm{M}$ KIN). Sarihan et al. (2005) used the hypocotyl explant of $P$. afra L. and obtained MR of 23.17 
(MS supplemented with $0.91 \mu \mathrm{M}$ thidiazuron TDZ and $0.98 \mu \mathrm{M}$ IBA).

Adventitious shoots on the explants of $P$. maritima were regenerated directly and indirectly. Also $P$. asiatica was regenerated directly and indirectly from hypocotyls, cotyledons and roots (Makowczyńska 2006; Makowczyńska et al. 2008).

A very high multiplication result (68.5 shoots per explant) in the case of first nodes from the top healthy shoots (derived from hypocotyl explants) used as explants cultured on MS with $0.45 \mu \mathrm{M}$ TDZ and $0.09 \mu \mathrm{M}$ IBA from other species of the genus Plantago $-P$. lanceolata L. was obtained by Khawar et al. (2005). Shoots were formed here only indirectly.

On the part of the shoots of $P$. maritima, obtained as a result of organogenesis during 6-week culture, adventitious roots developed spontaneously. This phenomena was often observed during micropropagation of the genus Plantago taxa (Makowczyńska 2006; Andrzejewska-Golec and Makowczyńska 2008). Rooting of the shoots during shoot micropropagation allows to omit the stage of rooting after the shoot micropropagation.

A great part of the shoots obtained for micropropagation of $P$. maritima were abnormal. Observed by us hydrous shoots it is abnormality often observed in in vitro culture (Wawrosch et al. 1999; Piątczak and Wysokińska 2003). This anomalous behaviour can be attributed to the excess of the growth regulators in the explants or supplied by the medium (Wawrosch et al. 1999). These anomalous shoots were rejected and only well-developed shoots were used for rooting and acclimatisation and plant obtained from there shoots were phenotypically normal.

Survival young plants of $P$. maritima was comparatively high and dependent on explant sources. Survival of the $P$. camtschatica was lower, but also dependent on sources of explants: $14 \%$ for plants regenerated from seedling tips and $27 \%$ for plants regenerated from other seedling explants (Andrzejewska-Golec and Makowczyńska 2008).

We have successfully demonstrated an efficient and reliable procedure for regeneration of $P$. maritima via different explants. This species was amenable to propagation from different kind of explants. Micropropagation of this plant may be an alternative method of its culture for different purposes. This method may have significance for protection of sea plantain. Micropropagation as alternative cultivation system for other vanishing plants among others in case of Atropa belladonna L., Centaurium erythraea Rafn, Drosera sp., Gentiana sp. (Zenkteler 1971; Momčilović et al. 1997; Królicka et al. 2001; Piątczak and Wysokińska 2003) was described.

\section{ACKNOWLEDGEMENTS}

The work is financed by the fund No. 502-13-486 from the Medical University of Łódź.

\section{LITERATURE CITED}

AHMAD I., LARHER F., STEWART G.R. 1979. Sorbitol, a compatible osmotic solute in Plantago maritima. New. Phytol. 82: 671-678.
ANDRZEJEWSKA-GOLEC E., MAKOWCZYŃSKA J. 2008. Micropropagation of Plantago camtschatica Link. Acta Soc. Bot. Pol. 77(4): 269-273.

BARNA K.S., WAKHLU A.K.1988. Axillary shoot induction and plant regeneration in Plantago ovata Forssk. Plant Cell Tiss. Organ Cult. 15: 169-173.

BUDZIANOWSKA A., SKRZYPCZAK L., BUDZIANIOWSKI J. 2004. Phenylethanoid glucosides from in vitro propagated plants and callus cultures of Plantago lanceolata. Planta Med. 70: 834-840.

CHANG I.D., LOCY R.D. 1996. In vitro regeneration of the plants of the halophyte Plantago maritima L. from primary explants and callus cultures. In: In Vitro Cell Develop. Biol. Program Issue World Congress on In Vitro Biology, San Francisco 1996. 32(3): Pt.2, 91 A.

GRUBEŠIĆ R.J., VUKOVIĆ J., KREMER D., VLADIMIRKNEŽEVIĆ S. 2005. Spectrophotometric method for polyphenols analysis: prevalidation and application on Plantago L. species. J. Pharm. Biomed. Anal. 38: 837-842.

KHAWAR K.M., SARIHAN E.O., SEVIMAY C.S., ÇÖÇÜ S., PARMAKSIZ I., URANBEY S., IPEK A., KAYA M. D., SANCAK C., ÖZCAN S. 2005. Adventitious shoot regeneration and micropropagation of Plantago lanceolata L. Period. Biol. 107: 113-116.

KRÓLICKA A., KAWIAK A., ŁOJKOWSKA E. 2001. Wprowadzenie do in vitro i mikrorozmnażanie roślin owadożernych $\mathrm{z}$ rodzin Droseraceae and Saraceniaceae. (Introduction and micropropagation of carnivorous plants of the Droseraceae and Saraceniaceae families) In: 52nd Congress of the Polish Botany Society. Materials of the sessions and symposia. Poznań, Poland, p. 163. (in Polish)

LIEBEZEIT G., KÜNNEMANN T.D., GAD G. 1999. Biotechnological potential of North Sea salt marsh plants - a review of traditional knowledge. J. Biotech. 70: 77-84.

MAKOWCZYŃSKA J. 2006. Mikrorozmnażanie Plantago asiatica L. Badania histologiczne i cytologiczne. (Micropropagation of Plantago asiatica L. Histological and cytological studies) Ph.D. dissertation. Medical University of Łódź. (in Polish)

MAKOWCZYŃSKA J., ANDRZEJEWSKA-GOLEC E. 2003. Micropropagation of Plantago asiatica L. through culture of shoot-tips. Acta Soc. Bot. Pol. 72: 191-194.

MAKOWCZYŃSKA J., ANDRZEJEWSKA-GOLEC E. 2007. Micropropagation of Plantago maritima L. In: 3rd Country Congress of Biotechnology. Agricultural University Poznań. 9-12 September 2007. (in Polish)

MAKOWCZYŃSKA J., ANDRZEJEWSKA-GOLEC E., SLIWINSKA E. 2008. Nuclear DNA content in different plant materials of Plantago maritima L. cultured in vitro. Plant Cell Tiss. Organ Cult. 94: 65-71. DOI 10. 1007/s11240-008-9387-8.

MOMČILOVIĆ I., GRUBEŠIĆ D., NEŠCOVIĆ M. (1997). Micropropagation of four Gentiana species (G. lutea, G. cruciata, G. purpurea and G. acaulis). Plant Cell Tiss. Organ Cult. 49: 141-144.

MOORE D.M., WILLIAMS C.A., YATES B. 1972. Studies on bipolar disjunct species. II Plantago maritima L. Bot. Notiser 125: 261-272.

MURASHIGE T., SKOOG F. 1962. A revised medium for rapid growth and bioassays with tabacco tissue culture. Physiol. Plant. 15: 473-497.

PIĄTCZAK E., WYSOKIŃSKA H. 2003. In vitro regeneration of Centaurium erythraea Rafn from shoot tips and other seedling explants. Acta Soc. Bot. Pol. 72: 283-288.

PIOTROWSKA H. 2001. Plantago maritima L. Babka nadmorska. In: Polska czerwona księga roślin. Paprotniki i rośliny kwiatowe. (Polish red data book of plants. Pteridophytes and flowering plants). Kazimierczakowa R., Zarzycki K. (eds). Instytut Botaniki im. W. Szafera i Instytut Ochrony Przyrody, PAN, Kraków, pp. 347-348. (in Polish with English summary) 
PRAMANIK S., CHAKRABORTY S., RAYCHAUDHURI S.S. 1995. In vitro clonal propagation and characterization of clonal regenerants of Plantago ovata Forssk by isozyme analysis. Cytobios 82: 123-130.

RŘNSTED N., GÖBEL E., FRANZYK H., JENSEN S.R., OLSEN C.E. 2000. Chemotaxonomy of Plantago. Iridoid glucosides and caffeoyl phenylethanoid glycosides. Phytochemistry 55 : 337-348.

SARIHAN E.O., KHAWAR M.D., ÖZCAN S. 2005. Prolific adventitious shoot regeneration from black psyllium (Plantago afra L.). Gen. Appl. Plant Physiol. 31: 81-87.
WAWROSCH C., MASKAY N., KOPP B. 1999. Micropropagation of the threatened Nepalese medicinal plant Swertia chirata Buch.-Ham. ex Wall. Plant Cell Rep. 18: 997-1001.

www - the Minister of Environmental Directive from 9 July 2004: http://www.salamandra.org.pl/prawo/Ochrona_gatunkowa_roslin (in Polish)

ZENKTELER M.A. 1971. Development of new plants from levels and roots of Atropa belladonna $\mathrm{L}$. in the in vitro culture. Acta Soc. Bot. Pol. 40: 305-313. 